\title{
Synchronization of Poda Na Lima and Da'wah
}

(Case Study in Madina Regency as a Philosophical Review)

\author{
Dr. Sahrul, M.Ag ${ }^{1}$ \\ ${ }^{I}$ Lecturer at Da'wah Faculty, Islamic State University (UINSU/IAIN), Medan, Indonesia
}

\begin{abstract}
Mandailing ethnic viewed from religion and culture, is regarded as a religious ethnic, fanatic and consistent on his culture inherited by his ancestor for generations. One form of cultural philosophy adopted and grounded in the community is known as poda na lima. Poda means teachings, advice, or guidance of life. Na means that/which and lima means five. Poda na lima means five guidance of life consisting of: 1)Paias ateатети (clean your hearts), 2)Paias pamatangmu (clean your body), 3) Paias parabitonmu (clean your shirt), 4) Paias bagasmu(clean your house), 5). Paias pakaranganmu (clean your home yard). All of the five guidance of life or poda na limahave the same mission with da'wah, that is an invitation to people to always do good things, amar makruf and nahi mungkar in order to achieve happiness in this world and hereafter.
\end{abstract}

Keywords: synchronization ; poda na lima; da'wah; Mandailing ethnic

\section{INTRODUCTION}

Madina Regency (Mandailing Natal) is one of 14 regencies in North Sumatra Province with Moslem majority and followers of Ahlussunnah wa al Jamaah (Aswaja) with Imam Shafi'I's mahzabwhich is identical to the old, where the organizations are Nahdlatul Ulama (NU) and Al-Jam'iyatul Washliyah. In da'wah term, they are called conservatives. And only few people of modernist Islamic which is identic to young generation as Muhammadiyah. The reason, Muhammadiyah is called as an Islamic organization because it is regarded as a new organization, Wahabiyah and not being accommodating to the local Islamic cultures such as plain flour, marhaban, tahlilan, towards the day and rescue death. Indeed, Prophet Muhammad never practices this culture.

In terms of ethnicity, this area is inhabited by the ethnic majority, Mandailing. This ethnic is very strong indigenous tradition, language, culture, solidarity, tribal and religious fanatics. Mandailing has a lot of clan: Nasution, Lubis, Batubara, Daulay, Matondang, Rangkuti, Parinduri and Pulungan. Nasution and Lubis are the largest compared by other clans. Because in the area of Mandailaing Godang, now it is known as Panyabungan city, is under the command of Nasution while in the area of Mandailaing Julu, now it is known as Kotanopan,, is under the command of Lubis (Pangaduan Lubis, 2010: 19). Each clan is quite harmonious, tolerant, friendly, have a kinship, not despise each other, but each maintains ukhuwwah Islam and silaturrahim. Patrilineal lineage, especially in the case of family succession, inheritance, legitimacy and identity.

Mandailing ethnic, as a religious community, has a diverse culture, one of them which is quite popular called poda na lima. Poda is interpreted as teachings, life guidance or advice, while na meansthat/whichand limameans five. Simply,poda na lima means five guidance of life consisting of:

1). Paias ate-atemu (clean your hearts)

2). Paias pamatangmu (clean your body)

3). Paias parabitonmu (clean your shirt)

4). Paias bagasmu (clean your house)

5). Paias pakaranganmu (clean your home yard)

Based on the research results, poda na lima above is not limited to mere expressions, traditions, advice of the ancestors, traditional leaders, and the scholars but it also contains philosophical values which are synchronized with da'wah. Culture is still grounded in ethnic communities of Mandailaing until today delivered on the advice of wedding, party culture, taklim, taught to students in elementary school and written in the customary book, billboard in houses and public place, even we can see it at the gate of the Madina district found a great billboard of poda na lima. The goal is that people know about the culture of Mandailaing ethnic and uses it as a way of life for individuals, families andcommunities.

DOI: $10.9790 / 0837-2110024650 \quad$ www.iosrjournals.org $\quad 46 \mid$ Page




\section{METHODOLOGY}

Research on poda na lima (five guidance of life) is a qualitative research attempted to describe the results of research in the form of written or spoken as a result of observation, interviews and documentation study. Characteristic of qualitative research are empiricism, idealism, humanism and rationalism (Bungin, 2017: 4-5). The data source consists of primary and secondary data. Primary or principal source of data are obtained from traditional leaders, community leaders, preachers and ulema. Secondary sources are obtained from books, magazines, bulletins and brochures. Data collection tool are observation, interview and documentation study.

This research uses an ethnographic approach introduced by Spardley, Charles Winnick and Roger M.Keesing (1989). Ethnographic work is an attempt to describe the culture of a community or group of people. The goal is to understand the views of community life among others influenced by the beliefs and culture (Patji, 2005: 15). There are three analytical techniques used in ethnography, namely 1). Domain. 2). Taxonomy. 3). Componential. Domain analysis is used to describe the culture from the outside only. Taxonomic analysis focuses on specific domains, the domain disaggregated into sub-domains in detail which are generally found in the same family. Average component analysis is the analysis used to view the social phenomena of culture. Here, this research also uses emic methodand ethics method. Emic method is applied to see the inner side of the cultural behaviors. While ethics methods is applied to see the outside of the cultural behaviors that can be tested the similarities and differences in cultural actors. There are several steps of ethnographic approach, namely:

1. Identifying the culture to be studied

2. Identifying the significant variables of culture under study

3. Launching a literature review

4. Learning and understanding the culture of the community

5. Looking research informants

6. Collecting data

7. Describing the culture and developing theories

8. Establishing a conclusion.

\section{DISCUSSION}

Poda na lima is ethnic cultural philosophy of Mandailaing which serves as the basis of religion, culture, education, communication and social. In fact, it also has been used by preachers as one of the strategies in developing cultural of da'wah in Madina. As a result, Mandailing ethnic can understand the relationship between religion and culture. And understanding where the culture is against the teachings of Islam and not. For more details, the relationship between poda na lima with da'wah can be seen in the following explanation:

\section{Paias ate-atemu (clean your heart)}

Human beings as creatures of Allah is the best creatures on earth consisting of three aspects, namely jismiyah, nafsiah and spritual. Jismiyah covers all aspects of human organs; head, neck, mouth, chest, abdomen, arms and legs. Nafsiah aspect includes thoughts, feelings and desires. Spritual aspect is the overall potential of the human psyche that emanates from two dimensions of al-ruh and al-fitrah. Ahmad Mubarok said that human beings has two elements, namely physical and spiritual. Physical is the outer side of the human being while spiritual is the inner side of the human (Mubarok, 2000: 47). Both elements are within the human beings and they are at a separate place. When people die, it will physically separate from the spiritual.The physical will be destroyed by the land and the spirit will return to God and someday be reunited (at-takwir: 7).

Shaping and guiding the physical aspect is not too difficult because the physical is passive and receptive. If people can meet the physical needs, it will be healthy. Rather complex problem is a spiritual guide because it contains three elements in it; an-nafs, al-aql and qalb. An-nafsmeans the soul of human beings 
created by Allah SWT must be maintained in perfect purity. Al-aql translated into Indonesian is sense, that hold and bind. On the other hand, the sense is possessed by humans to acquire knowledge. Qalb means change, move or turn. Psychologically, meaning heart of human condition is always back and forth, inconsistent.At one time, a man can be good but on the other hand a man can be bad, containing liver disease, cruel and rude (Baharuddin, 2007: xiii). Therefore, in a variety of social behaviors found in people, there are well behaved, diligent worship, prayers and noble man instead of found depraved; vindictive, spiteful, arrogant, perfidious, a miser and a liar.

In the perspective of $d a$ 'wah, it is not too difficult to clean the liver or spiritual. The source of all problems in the world is sourced from a heart that is not clean. A widespread culture of corrupt, dishonesty, social conflict, drug trafficking, the fight fellow Muslims, spiteful, arrogant, greedy and treasonous because the heart is not clean. A clean heart will produce taa'wun (sense of mutual help), tolerance, solidarity, honesty, sincerity, patience and resignation. In a clean heart will result in the human unconscious as a creation of God and will return to God. Therefore, the philosophy of culture paias ate-atemu is considered relevant to the social life.

\section{Paias pamatangmu (clean your body)}

Philosophically, clean your body every day is interpreted as you should clean your body from stains, odors and impurities including clean of large and small impurity. Interest clean the body will keep you healthy, fresh and protected from diseases. When doing worship, you should not be in contact with unclean thing. For Mandailing ethnic, paias (clean) your body two or three times a day and while welcoming the fasting month of Ramadan do Marpangir tradition (bath with water lime) in the river together; daughter, wife and friend. Pangiris cooked using bamboo as cooking lemang and should not be in a cauldron or pot because it does not feel the fragrance. The ingredients consist of lime, turmeric leaves, roses, jasmine and other types of flowers. This tradition is unique, interesting and judged not against the teachings of Islam though never practiced by the Prophet Muhammad. The goal is to welcome the fasting month of Ramadan.

\section{Paias parabitonmu (clean your clothes)}

Philosophically, paias parabitonmu means to wash clothes in everyday life.Clothes must not be dirty and smelly. Because the function of clothes on the body is as a self-identity, nature and cover the nakedness that looks gorgeous as a form of civilized society. For Mandailing ethnic, beautiful clothes is not only measured by the type of material, the fashion, the high price, pattern and color, but the clothes are always kept clean.

Many years ago, the term of paias parabitonmuis famoused by kuria (village head), traditional leaders and ulema. Until now the term is grounded among Mandailing ethnic. Basic reference Q.S. Al-A'raf / 7: 26, namely:

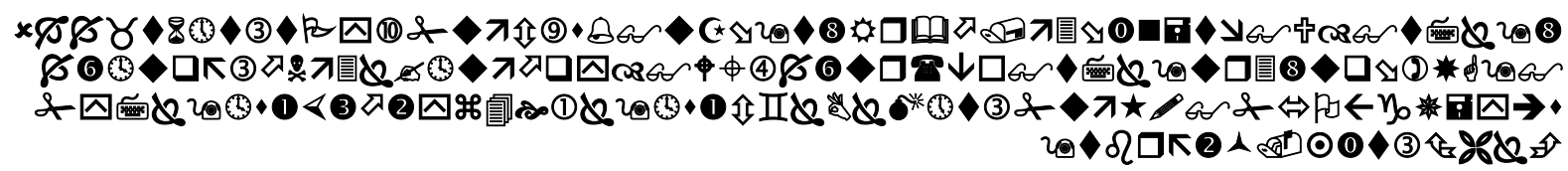

Meaning: O children of Adam! We provide clothing to cover your nakedness and as jewelry for you. But the clothing of piety that is better. Such are some of the signs of Allah,hopefully they remember. In Prophet Muhammad's hadith, it is said that cleanliness is part of faith.

\section{Paias bagasmu (clean your house)}

The house in Mandailings is called bagas, while Toba Batak language version called it as jabu (home). The house serves as a family residence, a place of rest, where caring for and raising children. My house is my castle, my house is my heaven. What is the philosophical meaning of clean the house? In the perception of Mandailing ethnic, a good house is not only judged by the magnificent building, architecture, multi-storey, fully furnished, bedroom lot, strategically located but supposing a living room, bedroom and bathroom are clean and free of dust. In the perception of da'wah, a clean home owners who believe, and sincerely practice the teachings of Islam.

Mandailing ethnic traditions, assess someone's house is clean or not then take a look at the living room and bathroom. This behavior does not mean in the category seek disgrace homeowners, and being nosy toward 
others. This tradition is also shared by other ethnic groups in North Sumatra. The responsibility of cleaning the house is located in the shoulder of the whole family. In general, it is a duty and responsibility of a wife and children who have grown up. The duty of the father is to make a living family lawful and good. The tools used to clean the house is broom fibers, broom sticks.

\section{Paias pakaranganmu (clean your home yard)}

Home yard cannot be separated by the building of the house. The house belonging to a beautiful, immaculate, stately, cool and shady eye is a house that has a wide yard, has a garden and has a seat at the front of the house, looking at the surrounding natural environment. The house is beautiful and gorgeous in philosophy of Mandailaing ethnic if the home page is clean from household waste, organic waste, foliage of trees, there are no long grass and ditch water channel smoothly. The tools used to clean the home yard are, machete, broom stick and trowel. In modern, if long grass then cut using a lawn mower. The concept of clean your house is now applied seriously by Madina district governments, village heads, heads of neighborhood, school principals, head office, custom dean, preachers, heads of the central market and the nazirof a mosque or mushalla. As a result, the area of Panyabungan: cities, villages, houses, offices, schools, houses of worship, schools look beautiful and clean in accordance with the values of $d a$ 'wah.For people who violate the rules of hygiene, reprimanded, are given advice, sanctions and penalties. Forms of advice; live clean, keep, do not litter, and dispose of waste in the space provided. The faithful who are intelligent people who always keep the environment clean. Shame, it is a part of faith. Even on the activities of taklim preachers always extend an invitation to keep the environment clean. Therefore, rightly called that Madina is a foyer of Mekkah in North Sumatra. Society truly practice the culture of poda na lima (five guidance of life).

\section{CONCLUSION}

Culture of poda na lima (five guidance of life) adopted by Mandailing ethnic is one element containing spiritual and four more shows about the physical element. Spiritual element is paias ate-atemu (clean your hearts).A physical element is paias pamatangmu (clean your body), paias parabitonmu (clean your clothes), paias bagasmu (clean your house) and paias pakaranganmu (cleanse your home yard). All elements are in line with $d a$ 'wahin the form of an invitation to the public to carry out the goodness, enjoining and forbidding unjust so as to obtain the happiness of living in the world and in the hereafter. Culture of poda na limaadopted Mandailings becomes an icon of Panyabungan and turns grounded in personal, family and community. Be Madina as a religious people, cultured and civilized.

\section{REFERENCES}

[1] Al-Quran al-Karim

[2] Aziz. Moh. Ali.2009. Ilmu Dakwah. Jakarta: Kencana.

[3] Baharuddin. 2007. Paradigma Psikologi Islami. Yogyakarta: Pustaka Pelajar.

[4] Bungin, Burhan.2007. Penelitian Kualitatif. Jakarta: Kencana.

[5] Harahap. 2010. Adat Istiadat Mandailing. Medan: Sumatera Utara.

[6] Lubis, Z. Panduan. 2010. Asal-usul Marga-Marga di Mandailing. Jakarta: Pustaka Widiasarana.

[7] Lubis, Z. Pangaduan dan Zulkifli Lubis. 1998. Sipirok Na Soli Bianglala Kebudayaan Masyarakat Sipirok. Medan: Univesitas Sumatera Utara.

[8] Mubarok, Ahmad. 2000. Jiwa Dalam Al-Quran. Jakarta: Paramadina.

[9] Patji, Abdul Rahman.2005.Agama dan Pandangan Hidup, Kajian Tentang Religi Lokal di Bali dan Lombok.Jakarta: LIPI.

[10] Pelly, Usman. 1994. Urbanisasi dan Adaptasi Peranan Misi BudayaMinangkabau dan Mandailing. Jakarta: LP3ES. 
[11] Sahrul, 2014. Filsafat Dakwah Tinjauan Ontologi, Epistemologi dan Aksiologi. Bandung: Citapustaka Media.

[12] Sarumpaet. JP. 1995. Kamus Batak Indonesia. Jakarta: Erlangga. 